\title{
A comparison of clinical simulation and classical learning for airway management in medical undergraduate students: a randomized controlled trial
}

\author{
Niño MC, Ferrer LE, Benítez D, Romero DJ. \\ Fundación Santa Fe de Bogotá. Bogotá, Colombia
}

\section{Introduction}

Clinical simulation is a useful learning method in medical teaching (1). Multiple studies have shown its benefits over classical learning technique (2). Research on simulation of airway management has focused on endotracheal intubation training, while on ventilation via facemask is scant (3). The investigators compared both learning methods regarding the acquirement of basic skills for airway management by medical students.

\section{Materials and methods}

A total of 102 last year medical students were randomized to clinical simulation or classical learning (51 per group). First group received a 3-hour long training on airway management on the first day of their 28-day anesthesia rotation, while classical learning did not. On the last day of rotation, they were evaluated based on a validated instrument of scores. Primary outcome was airway management scores. Secondary outcomes were rate of success of intubation and incidence of complications.

\section{Results}

Students in the clinical simulation group obtained a significant higher score than classical learning in ventilation but not in endotracheal intubation ( $P=0.046$ and $P=0.065$, respectively).

\begin{tabular}{|c|c|c|c|}
\hline Average score & $\begin{array}{l}\text { Control } \\
\text { Group } \\
n=51\end{array}$ & $\begin{array}{c}\text { Simulation } \\
\text { Group } \\
n=51\end{array}$ & $P$ value \\
\hline $\begin{array}{l}\text { Positive } \\
\text { Pressure } \\
\text { Ventilation }\end{array}$ & $6.9(1.3)$ & $7.4(1)$ & $0.046 *$ \\
\hline $\begin{array}{l}\text { Endotracheal } \\
\text { Intubation }\end{array}$ & $5(1.1)$ & $5.4(1)$ & 0.065 \\
\hline
\end{tabular}

Table 1. Overall score for positive pressure ventilation and endotracheal intubation

\begin{tabular}{cccc}
\hline & $\begin{array}{c}\text { Control } \\
\text { Group } \\
\mathbf{n}=\mathbf{5 1}(\%)\end{array}$ & $\begin{array}{c}\text { Simulation } \\
\text { Group } \\
\mathbf{n}=\mathbf{5 1}(\%)\end{array}$ & P value \\
\hline $\begin{array}{c}\text { Accidental } \\
\text { esophageal } \\
\text { intubation }\end{array}$ & $2(3.9)$ & $0(0)$ & 0.495 \\
\hline Oral trauma & $2(3.9)$ & $1(2)$ & 1.000 \\
\hline
\end{tabular}

Table 2. Incidence of complications

\begin{tabular}{cccc}
\hline & $\begin{array}{c}\text { Control } \\
\text { Group } \\
\mathbf{n}=\mathbf{5 1}(\%)\end{array}$ & $\begin{array}{c}\text { Simulation } \\
\text { Group } \\
\mathbf{n}=\mathbf{5 1}(\%)\end{array}$ & P value \\
\hline $\begin{array}{c}\text { Successful } \\
\text { intubation }\end{array}$ & $40(78.4)$ & $47(92.2)$ & 0.091 \\
\hline $\begin{array}{c}\text { First pass } \\
\text { success }\end{array}$ & $32(62.8)$ & $37(72.6)$ & 0.291 \\
\hline
\end{tabular}

Table 3. Successful intubation

\section{Conclusion}

Clinical simulation in addition to clinical practice demonstrated to be educationally effective for ventilation via facemask. Endotracheal intubation skills acquisition didn't differ between the groups, suggesting that last one is a more complex intervention, and that undergraduate students may benefit from longer training in this context.

\section{References}

1. Howells TH, Emery FM, Twentyman JE: Endotracheal intubation training using a simulator. An evaluation of the Laerdal adult intubation model in the teaching of endo- tracheal intubation. Br J Anaesth 1973; 45:400-2.

2. Barsuk D, Ziv A, Lin G, Blumenfeld A, Rubin O, Keidan I, Munz Y, Berkenstadt H: Using advanced simulation for recognition and correction of gaps in airway and breathing management skills in prehospital trauma care. Anesth Analg 2005; 100:803-9.

3. Wong W, Kedarisetty S, Delson N, Glaser D, Moitoza J, Davis DP, Hastings RH: The effect of cross-training with adjustable airway model anatomies on laryngoscopy skill transfer. Anesth Analg 2011; 113:862-8. 